Editorial Content

Open Access

\title{
Scientia Pharmaceutica, Autorenhinweise 2016
}

Sci Pharm. 2016; 84: 219-230

doi:10.3797/scipharm.aut-16-01

Die Zeitschrift Scientia Pharmaceutica (www.scipharm.at) erscheint vierteljährlich jeweils am Quartalsende und ist ein Medium zur Publikation von Originalarbeiten, Kurzmitteilungen und ausgewählten Übersichtsarbeiten aus allen wissenschaftlichen Disziplinen der Pharmazie und angrenzenden Gebieten sowie der pharmazeutischen Praxis.

Scientia Pharmaceutica (ISSN 0036-8709, e-ISSN 2218-0532) wird in zahlreichen Datenbanken laufend indexiert; darunter auch: Chemical Abstracts (SciFinder), Scopus, PubMed, PubMed Central, International Pharmaceutical Abstracts, Google Scholar, Natural Product Updates, CAB Abstracts, EBSCO, Chimica, Chemlnform, ProQuest, Embase / Excerpta Medica, Medicinal and Aromatic Plants Abstracts, etc.

Manuskripte können entweder in Deutsch oder Englisch verfasst werden und sollten möglichst elektronisch per E-Mail an office@scipharm.at eingereicht werden. Der Manuskripteingang wird dem Korrespondenzautor per E-Mail bestätigt.

Die Schriftleitung behält sich vor, Arbeiten mit groben sprachlichen, formalen oder inhaltlichen Mängeln abzulehnen (siehe auch Kriterien für eine sofortige Ablehnung). Vor der Einreichung von Übersichtsarbeiten ist eine Zusammenfassung der Redaktion zu schicken. Es werden nur unveröffentlichte Arbeiten angenommen; sind Teilergebnisse bereits veröffentlicht, so sind diese korrekt zu zitieren und die entsprechenden Arbeiten beim Einreichen mitzuschicken.

Die eingelangten Manuskripte werden einem Begutachtungsverfahren (peer review) unterzogen, das ein zugeteilter Fachredakteur mit Hilfe von externen Gutachtern leitet. Bei der Einreichung sollten 3-5 unabhängige und kompetente Gutachter vorgeschlagen werden (komplette Anschrift und E-Mail-Adressen sind erforderlich). Die endgültige Entscheidung obliegt der Schriftleitung.

Mit der Einreichung eines Manuskriptes bestätigt der Autor, die Erlaubnis seiner CoAutoren zu besitzen, folgende Abmachungen zu tätigen. Er bestätigt, in seinem Namen so wie im Namen der Co-Autoren, dass...

die eingereichte Arbeit weder in einer anderen Zeitschrift veröffentlicht wurde noch sich unter Begutachtung befindet, noch gegen Urheber- oder andere Rechte dritter verstößt;

er der einzige Autor ist / sie die einzigen Autoren sind und die Befugnis besitzt / besitzen, diese Abmachung einzugehen und Lizenzrechte der Österreichischen Pharmazeutischen Gesellschaft zu gewähren;

die Arbeit weder rechtwidrig noch verleumderisch ist und die Veröffentlichung gegen keinerlei Verträge, Verschwiegenheitsabkommen oder Geheimsachen verstößt; 
er / sie für die Vollständigkeit und Rechtschaffenheit des Artikels gesorgt hat / haben. Nach bestem Wissen und Gewissen des Autors / der Autoren so wie nach dem Stand der Wissenschaft sind die in dem Artikel getätigten Aussagen wahr und die genaue und sorgfältige Wiederholung der angegebenen Arbeitsvorschriften führt weder zu Verletzungen noch zu Krankheit;

die eingereichte Arbeit - sofern angenommen - unter den Creative Commons 3.0-Lizenzbestimmungen (http://creativecommons.org/licenses/by/3.0/) veröffentlicht wird und der Österreichischen Pharmazeutischen Gesellschaft lizenziert wird. Zusammengefasst bedeutet dies, dass der Autor / die Autoren das Copyright behalten und die Arbeit open access veröffentlicht wird: Es ist jedermann gestattet, das Werk zu vervielfältigen, zu verbreiten und öffentlich zugänglich zu machen; Abwandlungen bzw. Bearbeitungen des Inhaltes anzufertigen; kommerziell zu nutzen zu den folgenden Bedingungen: Sie müssen den Namen des Autors/Rechteinhabers in der von inm festgelegten Weise nennen (zitieren) und im Falle einer Verbreitung müssen Sie anderen die Lizenzbedingungen, unter welche dieses Werk fällt, mitteilen. Jede der vorgenannten Bedingungen kann aufgehoben werden, sofern dies der Rechteinhaber einwilligt.

Vor der (Online-)Veröffentlichung jeder wissenschaftlich angenommenen Arbeit ist eine Publikationsgebühr von $€ 250,-$ zu entrichten. Die Onlineversion der Zeitschrift kann kostenlos gelesen werden; Informationen zum Abonnement der Druckversion sind online verfügbar: www.scipharm.at/bestellung

\section{Checkliste für die Einreichung von Manuskripten}

$\square \quad$ Wurde die aktuelle Version der Autorenrichtlinien von www.scipharm.at/autoren heruntergeladen?

$\square \quad$ Wurde das Manuskript entsprechend den Autorenrichtlinien, möglichst mit Hilfe der MS Word-Manuskriptvorlage erstellt?

$\square \quad$ Überprüfung auf Rechtschreibfehler? (Externe) Sprachkorrekturen?

$\square \quad$ Einzelne MS Word-Datei eingereicht? Alle Tabellen, Grafiken und Schemata im Hochformat in geeigneter Qualität (hohe Auflösung) und an der entsprechenden Stelle im Manuskript eingefügt?

$\square \quad$ E-Mail-Adresse der Autoren eingefügt (zumindest Korrespondenzautor)?

$\square \quad$ Vollständige Namen aller Autoren (kompletter Vor- und Nachname)?

$\square \quad$ Kriterien für sofortige Ablehnungen gelesen?

$\square \quad$ Korrekte Formatierung der Zitate?

Publikationsgebühr bekannt?

$\square \quad$ Begleitschreiben mit allen relevanten Informationen für die Schriftleitung (ethische Stellungnahmen; unabhängige Gutachtervorschläge inkl. E-Mail- und Postadresse; etc.) 


\section{Hinweise zur Manuskriptgestaltung}

Es wird dringend empfohlen vor Erstellung des Manuskriptes, aktuelle Artikel der Zeitschrift als Referenz für die Formatierung heranzuziehen. Außerdem steht eine MS Word-Vorlage zur Verfügung, die unter http://www.scipharm.at/autoren heruntergeladen werden kann.

\section{Abbildungen und Tabellen}

Abbildungen, Schemata, Grafiken und Tabellen müssen in den Text in geeigneter Größe und Qualität ausschließlich im Hochformat eingebettet werden. Bitte beachten Sie, dass die Lesbarkeit auch noch nach der produktionsbedingten Größenreduktion auf 70\% gegeben sein muss.

Chemische Strukturen müssen mit einem geeigneten Programm (vorzugsweise ACD/ChemSketch) gefertigt sein und eine einheitliche Größe und Form innerhalb des Manuskripts aufweisen.

\section{Nomenklatur}

Die chemische Nomenklatur muss den IUPAC Regeln folgen und sollte mit einem professionellen Computerprogramm kontrolliert werden; Die botanische Nomenklatur muss in Übereinstimmung mit dem "International Code" oder "Englers Syllabus der Pflanzennamen" erfolgen.

\section{Charakterisierung neuer Substanzen}

Alle neu erhaltenen Verbindungen bedürfen einer sorgfältigen und dem stand der Technik entsprechenden Analyse; typischerweise: ${ }^{1} \mathrm{H}-\mathrm{NMR},{ }^{13} \mathrm{C}-\mathrm{NMR}, \mathrm{MS}$ (inkl. Fragmentierungsmuster bei El-MS), Elementaranalyse; Schmelzpunkt für feste Substanzen. Weitere Techniken wie z. B. IR, HRMS, X-NMR, 2D NMR, Röntgenstrukturanalyse, HPLC, etc. können erforderlich sein und sollten nach Möglichkeit angewandt werden. Originalspektren sind - sofern nicht bereits als Zusatzmaterial eingereicht - auf Verlangen nachzureichen.

Für pharmakologische Untersuchungen von Pflanzenextrakten sind charakteristische DC/HPLC-Chromatogramme erforderlich (fingerprint) um z. B. die Vergleichbarkeit der Ergebnisse zu gewähren.

\section{Fiktives Beispiel:}

Farblose Kristalle FP $118-120^{\circ} \mathrm{C}$ (wässr. Ethanol). MS (m/z, \%): $202\left(\mathrm{M}^{+}, 3\right), 184(36), 73$ (100). IR (KBr), v, $\mathrm{cm}^{-1}: 1683,1645 .{ }^{1} \mathrm{H}-\mathrm{NMR}\left(500 \mathrm{MHz}, \mathrm{CDCl}_{3}, \mathrm{TMS}\right): \delta 8.74-8.80(\mathrm{~m}$, $2 \mathrm{H}, \mathrm{H}-3,5), 8.18\left(\mathrm{dd},{ }^{3} J_{\mathrm{H} 2, \mathrm{H} 1}=7.7 \mathrm{~Hz},{ }^{4} J_{\mathrm{H} 2, \mathrm{H} 7}=1.1 \mathrm{~Hz}, 1 \mathrm{H}, \mathrm{H} 2\right), 7.68(\mathrm{~s}, 1 \mathrm{H}, \mathrm{H}-6), \ldots$ ${ }^{13} \mathrm{C}-N M R$ (125 MHz, DMSO- $d_{6}$, TMS): $\delta 175.4(\mathrm{COOH}), 136.3(\mathrm{C}-7), 134.1\left(\mathrm{C}_{\mathrm{q}}\right), 128.0$ $(\mathrm{CH}), 127.6(\mathrm{CH}), 54.3\left(\mathrm{CH}_{2}\right), \ldots$ HRMS: Berechnet für $\mathrm{C}_{11} \mathrm{H}_{10} \mathrm{~N}_{2} \mathrm{O}_{2}$ : 202.0742. Gefunden: 202.0746. Analyse Berechnet für $\mathrm{C}_{11} \mathrm{H}_{10} \mathrm{~N}_{2} \mathrm{O}_{2}$ : C, 65.34; $\mathrm{H}, 4.98 ; \mathrm{N}, 13.85$. Gefunden: $\mathrm{C}$, $65.04 ; \mathrm{H}, 5.22 ; \mathrm{N}, 13.60$. 


\section{Sprachkorrekturen}

Die Verantwortung für sprachlich einwandfreie Arbeiten liegt bei den Autoren. Bei Veröffentlichungen in einer anderen als der Muttersprache sind möglichst externe Institutionen zu beauftragen und die entsprechenden Referenzen im Begleitschreiben bei der Einreichung mitzuteilen. Diverse Sprachinstitute sind unter www.scipharm.at/autoren verklinkt. Sci Pharm spricht jedoch ausdrücklich keine Empfehlung für eine bestimmte Firma aus und hat keinerlei finanzielle Verbindungen diesbezüglich.

\section{Zusatzmaterial}

Spektren, umfangreiche Tabellen und Abbildungen können bzw. sollen als Zusatzmaterial in der elektronischen Ausgabe veröffentlicht werden.

\section{Ethische Stellungnahmen der Autoren}

\section{Interessenskonflikte}

Ein Interessenskonflikt besteht sobald ein Individuum (oder dessen Institution) eine finanzielle, persönliche oder berufsmäßige Beziehung zu anderen Personen oder Institutionen besitzt, die seine Entscheidungen und Handlungen beeinflussen könnte. Interessenskonflikte entstehen aus solchen Situationen unabhängig davon, ob die Entscheidung konkret oder möglicherweise beeinflusst ist.

\section{Beispiele für eine Stellungnahme}

Die Autoren bestätigen ihre Unabhängigkeit. / ABC besitzt ein Patent für ... / DEF erhält als Berater ein Honorar von der Firma XYZ ...

\section{Patientenaufklärung und -einverständnis, Befürwortung Ethikkommission}

Patienten haben ein Recht auf Privatsphäre, gegen das nicht verstoßen werden darf. Jegliche Information, die den Patienten identifizieren könnte (z. B. Namen, Initialen, Krankenhausnummern, etc.) dürfen nicht veröffentlicht werden, sofern dies nicht aus wissenschaftlicher Sicht erforderlich ist und der betreffende Patient (bzw. seine Eltern oder sein Vormund) seine schriftliche Zustimmung gibt.

Bei Untersuchungen von Menschen muss im Abschnitt „Experimentelles” bestätigt werden, dass die ethischen Standards der Helsinki-Deklaration von 1964 (erneuert 2000, http://www.wma.net/e/policy/b3.htm) eingehalten wurden und dass eine Zustimmung des zuständigen Ethikkomitees vorliegt.

\section{Tierrechte}

Bei Tierexperimenten muss im Abschnitt „Experimentelles” bestätigt werden, dass die nationalen und internationalen ethischen Standards eingehalten wurden und dass eine Zustimmung des zuständigen Ethikkomitees vorliegt.

\section{Literatur}

Literaturverweise im Text werden fortlaufend in eckigen Klammern nummeriert z. B. [2-4] und im Abschnitt "Literatur" aufgelistet. Schriftformat ist Arial 10, normal, einzeilig. Fußbzw. Endnoten dürfen nicht verwendet werden. Die Zitierung der Literatur erfolgt in 
Anlehnung an den "Vancouver style" [1] wie unten dargestellt (Bücher [2], Zeitschriften $[3,4])$.

$\square \quad$ Autor: In der ersten Zeile eines Zeitschriftenzitates sind alle Autoren in der Originalreihenfolge anzugeben. Jedem Nachnamen werden die Initialen seiner Vor- bzw. Mittelnamen (max. 2) nachgestellt. Einzelne Autoren werden mittels Beistrich getrennt. Nach dem letzten Autor erfolgt ein Punkt und ein weicher Zeilenumbruch (durch gleichzeitiges Drücken der Enter- und Shifttaste)

$\square \quad$ Titel: Der Titel wird wie im Original wiedergegeben, gefolgt von einem Punkt und einem weichen Zeilenumbruch.

$\square \quad$ Zeitschrift: Der Titel wird abgekürzt; alle Wörter beginnen mit einem Großbuchstaben; keine Punkte außer nach dem letzten Wort gefolgt von einem Leerzeichen. Danach das Erscheinungsjahr, gefolgt von einem Strichpunkt und einem Leerzeichen. Dann die Bandnummer, gefolgt von einem Doppelpunkt und eine Leerzeichen. Die Heftnummer wird bei fortlaufend nummerierten Zeitschriften nicht angegeben. Die komplette Anfangs- und Endseite werden mit einem Halbgeviertstrich (= Bindestrich, - ) aber ohne Leerzeichen verbunden. Am Ende erfolgt ein Punkt und ein weicher Zeilenumbruch, um eine DOINummer hinzuzufügen, bzw. ein normaler Zeilenumbruch, um mit dem nächsten Zitat fortzufahren.

DOI-Nummer: Die DOI-Nummern werden ohne Leerzeichen eingefügt gefolgt von einem normalen Zeilenumbruch. DOI-Nummern für das komplette Literaturverzeichnis können auch auf einmal auf der Internetseite http://www.crossref.org/SimpleTextQuery nach einmaliger Registrierung eingefügt und zugeordnet werden.

Die einreichenden Autoren sind verantwortlich für korrekte Daten und exakte Formatierung der Literaturzitate.

[1] International Committee of Medical Journal Editors.

Uniform requirements for manuscripts submitted to biomedical journals.

http://www.icmje.org/

[2] Hänsel R, Keller K, Rimpler H, Schneider G; eds.

Passiflora.

In: Hagers Handbuch der Pharm. Praxis. 5th ed. Volume 6, Drogen P-Z.

Berlin: Springer-Verlag, 1994: 34-49.

[3] Katritzky AR, Odens HH, Zhang S.

Novel Synthesis of 2,3-Dihydro-1,5-benzothiazepin-4(5H)-ones and 2H-1,4-Benzothiazin-3(4H)-ones. J Org Chem. 2001; 66: 6792-6796.

http://dx.doi.org/10.1021/j00101959

[4] Koch C, Reichling J, Schneeleb J, Schnitzler P.

Inhibitory effect of essential oils against herpes simplex virus type 2.

Phytomedicine. 2008; 15: 71-78.

http://dx.doi.org/10.1016/j.phymed.2007.09.003 


\section{Kriterien für eine sofortige Ablehnung}

Die Schriftleitung behält sich vor, eingereichte Arbeiten auch ohne Begutachtungsverfahren abzulehnen, insbesondere bei folgenden Mängeln:

Sprache \& Zeitschriftenstil

Arbeiten mit groben sprachlichen oder formalen Mängeln werden nicht begutachtet.

Ethische Stellungnahmen

Arbeiten ohne ausreichende Stellungnahme zu Interessenskonflikten, Menschenrechten (und Einverständniserklärung der Patienten) bzw. Tierrechten werden nicht bearbeitet.

\section{Substanzcharakterisierung}

Arbeiten ohne ausreichende analytische Untersuchung (z. B. ${ }^{13} \mathrm{C}-\mathrm{NMR}$ für neue Substanzen bzw. Chromatogramm des verwendeten Pflanzenextrakts) werden abgelehnt.

In-vitro antioxidative Wirkung

Ein Routine-Überprüfung auf in allen Pflanzen vorhandene in-vitro-Antioxidativität hat ohne Hinweis auf eine entsprechende in-vivo-Wirkung wenig Aussagekraft.

\section{Diverses}

Routinebestimmungen von $\mathrm{LD}_{50}$-Werten für neue Substanzen sind ethisch nicht vertretbar.

Fehlende Literaturzitate

Manuskripte ohne Diskussion und Zitierung relevanter Arbeiten werden sofort abgelehnt.

Spectrophotometrische und elektroanalytische Messmethoden, Schicht-Chromatographie

Wurden zu einer analytischen Problemstellung bereits moderne chromatographische Methoden publiziert, ist eine Veröffentlichung in der Scientia Pharmaceutica nur in gut begründeten Ausnahmefällen möglich.

\section{Nicht offizinelle Naturstoffe}

Arbeiten über die Verwendung oder Erprobung von nicht registrierten bzw. zugelassenen Naturstoffen als Hilfsstoff in neuen Formulierungen werden grundsätzlich abgelehnt.

Gleichzeitige quantitative Bestimmung mehrerer Substanzen

Autoren müssen den wissenschaftlichen Nutzen und die Neuigkeit in Vergleich zu bestehenden Methoden darlegen, insbesondere wenn nur eine neue Substanz zu einer bestehenden Kombination hinzugefügt wird oder wenn die Substanzen von bereits bekannten Kombinationen getauscht werden (z.B.; $A+B+C$ wenn $A+B, B+C$ und $A+C$ bereist bekannt sind).

Plagiate und Mehrfachpublikationen

Komplette und teilweise Plagiate sowie Einreichungen bereits (größtenteils) veröffentlichter Manuskripte werden abgelehnt. Die Schriftleitung behält sich die Sperrung der involvierten Autoren für weitere Einreichungen vor. 


\section{Scientia Pharmaceutica, Instructions for Authors 2016}

Scientia Pharmaceutica (www.scipharm.at), a peer-reviewed journal with quarterly appearance, is published at the end of every quarter of each year. It is a medium for publication of original papers, short communications, a limited number of reviews, and papers concerning pharmaceutical practice, referring to all scientific aspects of pharmacy and related disciplines.

The journal Scientia Pharmaceutica (ISSN 0036-8709, e-ISSN 2218-0532) is currently indexed by Chemical Abstracts (SciFinder), Scopus, PubMed, PubMed Central, International Pharmaceutical Abstracts, Google Scholar, Natural Product Updates, CAB Abstracts, EBSCO, Chimica, Medicinal and Aromatic Plants Abstracts, ChemInform, ProQuest, Embase / Excerpta Medica and many others.

Manuscripts should be prepared in English language and should be submitted via e-mail to office@scipharm.at. The receipt of the manuscript will be acknowledged via e-mail to the corresponding author.

Only unpublished material will be accepted. If partial results are published they have to be cited correctly and the corresponding publications have to be enclosed. The editors reserve the right to reject papers with linguistic or scientific deficiencies or lacks regarding the preparation of the manuscript (see also criteria for immediate rejection). Prior to the submission of reviews, an abstract must be sent to the editorial office for pre-evaluation.

The submitted manuscripts will be peer reviewed by external reviewers guided by a scientific editor. It is recommended to suggest 3-5 independent (different country and different publication history than authors!) and competent reviewers in the cover letter with full contacting information (including an official email address - no free mail accounts). It is incumbent upon the editors to make the final decision.

By submitting a manuscript the submitting / corresponding author agrees that he is authorized by his co-authors to enter into these arrangements and he warrants, on behalf of himself and his co-authors, that:

The article is original, has not been formally published in any other peer-reviewed journal, is not under consideration by any other journal and does not infringe any existing copyright or any other third party rights;

$\mathrm{He}$ is/they are the sole author(s) of the article and have full authority to enter into this agreement and in granting rights to Österreichische Pharmazeutische Gesellschaft are not in breach of any other obligation;

The article contains nothing that is unlawful, libelous, or which would, if published, constitute a breach of contract or of confidence or of commitment given to secrecy; 
He has/they have taken due care to ensure the integrity of the article. To his/their - and currently accepted scientific - knowledge all statements contained in it purporting to be facts are true and any formula or instruction contained in the article will not, if followed accurately, cause any injury, illness or damage to the user.

The article, if accepted, will be published under the Creative Commons License 3.0 (http://creativecommons.org/licenses/by/3.0/) and is licensed to Österreichische Pharmazeutishe Gesellschaft. In summary, this means that the copyright stays with the author(s) and that the article is published open access. Hence, anyone will be free to copy, distribute, and display the work, to make derivative works, and to make commercial use of the work under the following conditions: The original author must be given credit (citation) and for any reuse or distribution, it must be made clear to others what the license terms of this work are. Any of these conditions can be waived if the authors give permission.

A publication fee of $€ 250,-$ must be paid for every (scientifically) accepted paper prior to publication. Information on how to order the print version can be found online: www.scipharm.at/subscription

To achieve a rapid and cost-effective publication as well as a uniform appearance of Scientia Pharmaceutica, authors must adhere to the Instructions for Authors and the electronic manuscripts in Microsoft Word format should be ready for direct reproduction.

\section{Checklist for Manuscript Submission to Sci Pharm:}

$\square \quad$ Latest version of instructions downloaded from www.scipharm.at/authors?

$\square \quad$ Manuscript prepared preferably using the MS Word template?

$\square \quad$ Manuscript spellchecked and (external) language corrections done?

$\square \quad$ One single manuscript file in MS Word format submitted? Figures, schemes, and tables inserted in high resolution into the main text and no landscape format used?

$\square \quad$ Corresponding author designated and e-mail address(es) given?

$\square \quad$ Full names (first, middle and last names) and affiliation of all authors given?

$\square \quad$ Correct style for references? Citations placed in brackets, e.g. [1, 3, 6-9]

$\square \quad$ Criteria for Immediate Rejection read and understood?

$\square \quad$ Awareness of Publication fee?

$\square \quad$ Cover letter with all relevant information for editor:

o Relevant submitted or in press manuscripts

o Ethical statements (competing interests, informed consent, human \& animal rights)

o Complete contact information for independent referees given? 


\section{Guideline for manuscript preparation}

It is strongly recommended to look at the style of recent publications in Scientia Pharmaceutica prior to preparing a manuscript. Moreover, a MS Word template should be used and is available for download at http://www.scipharm.at/authors.

\section{Figures and tables}

Figures, schemes, graphs and tables must be inserted in the text appropriately in suitable size and quality. Landscape pages must not be used! Please note that the original size will be reduced to approx. $70 \%$ during printing.

Chemical structures should be drawn with a suitable drawing program (preferably ACD/ChemSketch).

\section{Nomenclature}

Chemical nomenclature should follow the rules of the IUPAC and should be proven by professional computer software; botanical nomenclature must be in agreement with the corresponding "International Code" or Englers "Syllabus der Pflanzennamen".

\section{Characterization of new compounds / plant extracts}

Typically, all new compounds need a detailed analysis with the following state-of-the-art techniques: ${ }^{1} \mathrm{H}$ NMR, ${ }^{13} \mathrm{C}$ NMR, MS (including fragmentation pattern for EI MS), elemental analysis; MP for solid compounds. Additional techniques such as IR, hrMS, X NMR, 2D NMR, X-Ray, HPLC, etc. may be required and all available data should be given whenever possible. The editors may request the submission of the original spectra.

TLC/HPLC fingerprint for plant extracts and fractions are required.

\section{Fictitious Example:}

Colorless crystals of $\mathrm{mp} 118-120^{\circ} \mathrm{C}$ (aqu. ethanol). MS (m/z, \%): $202\left(\mathrm{M}^{+}, 3\right), 184(36), 73$ (100). IR (KBr), v, cm ${ }^{-1}: 1683,1645 .{ }^{1} \mathrm{H}$ NMR (500 MHz, CDCl 3 , TMS): $\delta$ 8.74-8.80 (m, $2 \mathrm{H}, \mathrm{H}-3,5), 8.18\left(\mathrm{dd},{ }^{3} \mathrm{~J}_{\mathrm{H} 2, \mathrm{H} 1}=7.7 \mathrm{~Hz},{ }^{4} \mathrm{~J}_{\mathrm{H} 2, \mathrm{H} 7}=1.1 \mathrm{~Hz}, 1 \mathrm{H}, \mathrm{H} 2\right), 7.68(\mathrm{~s}, 1 \mathrm{H}, \mathrm{H}-6), \ldots{ }^{13} \mathrm{C}$ NMR (125 MHz, DMSO-d $d_{6}$ TMS): $\delta 175.4(\mathrm{COOH}), 136.3(\mathrm{C}-7), 134.1\left(\mathrm{C}_{\mathrm{q}}\right), 128.0(\mathrm{CH})$, $127.6(\mathrm{CH}), 54.3\left(\mathrm{CH}_{2}\right), \ldots$ HRMS: Calcd. for $\mathrm{C}_{11} \mathrm{H}_{10} \mathrm{~N}_{2} \mathrm{O}_{2}$ : 202.0742. Found: 202.0746. Anal. Calcd. for $\mathrm{C}_{11} \mathrm{H}_{10} \mathrm{~N}_{2} \mathrm{O}_{2}$ : C, 65.34; $\mathrm{H}, 4.98 ; \mathrm{N}, 13.85$. Found: $\mathrm{C}, 65.04 ; \mathrm{H}, 5.22 ; \mathrm{N}$, 13.60.

\section{Language corrections}

It is the responsibility of the authors who publish in a language other than their native one to ensure correct language usage by an external proof reading institution. Papers with poor language will be rejected! In the cover letter the utilized organization and the corresponding job number should be given. Editing certificates such as those from American Journal Experts (20-digit certification code must be provided) are accepted as proof for sufficient language quality of the submitted paper. Exemplary links to some companies that specialize in proof reading of scientific papers can be found at 
www.scipharm.at/authors. However, it should be noted that Sci Pharm does not recommend a specific organization and does not have any financial relation to one of them.

\section{Supporting Information}

Scans of original spectra, extensive tables and figures can be published as supplementary material in the online version.

\section{Ethical statements}

\section{Competing interests}

A competing interest exists when an individual (or the individual's institution) has financial, personal or professional relationships with other persons or institutions that could unduly bias his or her actions or judgments. Competing interests may arise from those relationships, irrespective of whether the judgment is actually affected or only potentially.

e. g. The authors declare no conflict of interest. / ABC holds a patent on ... / DEF is a consultant of the company XYZ ...

\section{Informed Consent \& Ethical Approvals (if applicable)}

Patients have a right to privacy that should not be infringed without informed consent. Identifying information, including patients' names, initials, or hospital numbers, should not be published in written descriptions, photographs, and pedigrees unless the information is essential for scientific purposes and the patient (or parent or guardian) gives written informed consent for publication.

Investigations with human subjects must state in the experimental section that the research followed the ethical standards formulated in the Helsinki Declaration of 1964, revised in 2000 (http://www.wma.net/e/policy/b3.htm), and was approved by the institutional human experimentation committee or equivalent. Any doubt about the ethical suitability of the human procedures used will result in the immediate rejection of the paper by the editors.

\section{Animal Rights (if applicable)}

Investigations with animals must state in the experimental section that the research followed the (inter)national ethical standards for the care and use of laboratory animals and was approved by the institutional animal experimentation committee or equivalent. Any doubt about the ethical suitability of the animal procedures used will result in the immediate rejection of the paper by the editors.

\section{References}

References appearing in the text must be numbered continuously in brackets, e.g. [2-4] and listed in the section "References". The footnotes or endnotes function of MS Word must not be used! References must be cited similarly to the "Vancouver style" [1] as shown below (books [2], journals [3, 4]). As far as possible, doi-numbers should be given in a separate line. 
$\square \quad$ Author: In the first line of each journal citation, all authors are given in the order they appear in the original text. The capitalized surname (family or last name) is given first and - after inserting a space - the given (first) names and middle names are converted to initials, for a maximum of two initials following each surname. Separate author names from each other with a comma and a space; end the author information with a period. Insert a soft-return (by pressing both the shift and enter key simultaneously) to start the title line.

$\square \quad$ Title: Enter the title of an article as it appears in the original publication. End the title with a period and insert a soft-return to start the journal line.

$\square \quad J o u r n a l:$ Abbreviate the journal's name, capitalize all words and abbreviations, do not use periods except after the last word which is followed by a period and a space. Insert the publication year followed by a semicolon and a space. Insert the volume followed by a colon and a space. Do not give issue numbers. Insert both the article's first and last page, separated by an en-dash (-) without any spaces. End the page number with a period. Insert a soft-return for entering the doi number (if available) or insert a hard-return to continue with a new citation.

$\square \quad$ Doi-number: Insert the doi-number without any spaces. End with a hard-return to continue with a new citation. Doi-numbers can be easily found by using the free web-service at http://www.crossref.org/SimpleTextQuery (requires one-time registration; just copy your reference list into the box and press 'submit').

It's the sole responsibility of the submitting authors to provide exactly formatted and correct citations!

[1] International Committee of Medical Journal Editors.

Uniform requirements for manuscripts submitted to biomedical journals.

http://www.icmje.org/

[2] Hänsel R, Keller K, Rimpler H, Schneider G; eds.

Passiflora.

In: Hagers Handbuch der Pharm. Praxis. 5th ed. Volume 6, Drogen P-Z.

Berlin: Springer-Verlag, 1994: 34-49.

[3] Katritzky AR, Odens HH, Zhang S.

Novel Synthesis of 2,3-Dihydro-1,5-benzothiazepin-4(5H)-ones and 2H-1,4-Benzothiazin-3(4H)-ones. J Org Chem. 2001; 66: 6792-6796.

http://dx.doi.org/10.1021/jo0101959

[4] Koch C, Reichling J, Schneeleb J, Schnitzler P.

Inhibitory effect of essential oils against herpes simplex virus type 2.

Phytomedicine. 2008; 15: 71-78.

http://dx.doi.org/10.1016/j.phymed.2007.09.003 


\section{Criteria for immediate rejection}

The editors reserve the right to reject submitted papers without peer reviewing, especially in the following cases:

\section{Language \& journal style}

Papers with poor language or papers lacking the journal's formal style as described in these instructions are not acceptable.

\section{Ethical guidelines}

Papers from authors who do not unambiguously clarify their competing interests or who do not provide sufficient information on human rights (and informed consent) as well as on animal rights will not be processed.

\section{Characterization of compounds}

Manuscripts will be rejected if sufficient analytical data (e. g. ${ }^{13} \mathrm{C}$ NMR for new compounds or a fingerprint chromatogram for plant extracts) are not provided.

\section{In-vitro antioxidant activity}

Because antioxidant activity is present in all plants, a routine screening with in-vitro assays has little meaning if no clear evidence is given for in-vivo activity.

\section{Miscellaneous}

Routinely determined $L D_{50}$ data for new compounds are ethically not acceptable.

\section{Missing citations}

Papers that do not discuss and cite relevant literature will be rejected.

Spectrophotometric and electroanalytic methods, Thin-Layer Chromatography

Papers mainly presenting such analyses are typically not acceptable when modern chromatographic methods are available for quantification.

\section{Simultaneous quantification}

Authors have to intensively argue the novelty and the value of their method in comparison to known methods, especially if they add only a new compound to an already well analyzed combination of compounds or if they interchange compounds of already well analyzed combinations (e.g.; $A+B+C$ when $A+B, B+C$ and $A+C$ are already known).

\section{Non officinal naturals}

Typically, papers dealing with the use and development of unapproved natural matrices will be rejected.

\section{Plagiarism and duplicate publication}

Such papers will be rejected and the editors may exclude the authors from future submissions. 